\title{
Competence Based Learning Implementation \\ for Public Administration Student Programs \\ to Improve Competency in Facing Industrial Era 4.0
}

\author{
Dewi Maharani \\ Departement of Public Administration, Faculty of Social and Political Sciences, Universitas Majalengka \\ (email: dewimaharani212@gmail.com)
}

\begin{abstract}
In line with the development of the industrial era 4.0, learning should be able to produce students who are not only capable of material content, but must also have soft skills to support skills or competencies for students. Today the need for the world of work can not only rely on muscle, but the ability of the brain to be something that is a fundamental need. Competencies applied to learning are in accordance with 21st century competencies, namely the ability to communicate, collaborate, think critically and problem solving, and have creativity and innovation. The method used is descriptive qualitative research sources are primary and secondary. Data processing techniques are carried out through four stages namely data reduction, data presentation, comparative analysis, and drawing conclusions. Data collection methods used are observation, interviews, and documentation. The results showed that the application of competency-based learning with communication competencies was inadequate, collaborative competencies were adequate, critical thinking and problem solving were inadequate, and creative and innovative competencies were inadequate. The implication of this research is that students must further improve their communication skills both through oral and written, increase critical power and always think solutively in solving problems, and always try to innovate to explore creativity in each individual.
\end{abstract}

\section{Keywords:}

competency based learning; competence in industrial era 4.0

\section{Introduction}

Changes in the world in various aspects of human life have a very significant change in impact on the needs of human life. If in the past to get a job, humans just rely on muscle strength alone is able to get a decent job. However, today not only rely on strength alone, but also dominates the use of the mind or brain to get work. Therefore it is necessary to improve human capabilities both in terms of soft skills and hard skills. One of the improvements in student competency through competency-based learning is an effort to improve human resources to be ready to adapt to the environment and be able to compete 
with the global world in order to survive. Entering 2000, four approaches to education were applied in Indonesia, namely: (1) life skills oriented education; (2) competency-based curriculum and learning; (3) production based learning; and (4) broadbased education (Masitoh, Dewi, Alinawati, Permasih, .2009).

Schunk (2008: 2) defines "Learning is enduring change in behavior, or in the capacity to behave in given fashion, which results from practice or other forms of experience". Learning is an effort to increase competence and have a visionary perspective and have behavioral changes that are sustainable based on the learning experience they have. Widiyanto (2011) concluded that the competency needs include knowledge (knowledge), ability skills (skills), behavior (attitude), and others (others) such as experience. agreed upon definition of competencybased learning was found in state and district policies or in interviews with administrators; however, researchers identified four common elements of the reform: 1 . Students must demonstrate mastery of all required competencies to earn credit or graduate. 2. Students advance once they have demonstrated mastery, and students receive more time, and possibly personalized instruction, to demonstrate mastery if needed. 3. Students are assessed using multiple measures to determine mastery, usually requiring that students apply their knowledge, not just repeat facts. 4. Students can earn credit toward graduation in ways other than seat time, including apprenticeships, blended learning, dual enrollment, career and technical education programs, and other learning opportunities outside the traditional classroom setting (Torres, Brett, \& Cox, 2015).

Competency-based learning approach is done through student-centered learning or Student Centered Learning (SCL). Students are placed as learning subjects. A competencybased approach must pay attention to the map of competency achievement in a field or program of expertise. Does a competency unit require pre-requisites or as pre-requisites for subsequent competencies (Febriana, Rina 2017). Furthermore Munthe (2009: 30) states that in designing learning must be contextualized with competency indicators, understanding the syntax of learning and assessment refers to the achievement of three aspects of cognitive, affective and psychomotor. The learning and learning process carried out in general is carried out in four stages of activities, namely (1) the planning phase of learning objectives; (2) early introduction of students' abilities and readiness; (3) learning process; and (4) learning evaluation. These four stages are carried out usually by emphasizing the final 
evaluation as the level of achievement of learning objectives as the end of a series of learning activities that include cognitive, affective and psychomotor aspects (Suryadi and Yusa. 2009). In theform of competency-based assessment, assessment is designed in the form of a scoring rubric which includes assignments, skills, attitudes, and appreciation that students must have in carrying out learning tasks in accordance with a particular job. (Baharuddin, 2017).

In general, the competency requirements needed by the workforce are divided into two large groups, namely technical skills and employability skills. Technical skills is the ability in the field of work which includes knowledge and skills, while employability skills are the ability to manage work attitude and behavior skills, which cover attitude and knowledge of the nature of work (Febriana, Rina 2017). The Secretary's Commission on Achieving Necessary Skills (SCANS) conducts studies to identify and describe the skills needed in the workplace (Kane, 1990). At first SCANS found seven functional skills, which are important skills for a worker, namely resource management, information management, social interaction, systems behavior and performance, human and technology interaction, and effective skills (Febriana, Rina 2017) .

The concept of learning design proposed by Suparman (2001: 25) "actually refers to the concept that states that the design and development of learning is a form of application of the implementation of learning activities". In the process, the learning design applies a systems approach, namely through systematic, logical and analytical steps. The system approach refers to an order that involves the input, process, output. In the context of learning design, the principle adopted is that learning outcomes as output, will greatly depend on how raw-input characteristics are, and how the quality of the processes carried out during learning takes place (Suherman, Amay.2012.).

Achievement of competency mastery refers to the National Education Standards (SNP) as a basis for assessment, which can be measured from the achievement of higher skills. Assessment in the competency-based learning model developed emphasizes more on the achievement of students 'competencies in cognitive (K), affective (A) and psychomotor (P) aspects, which are designed as a reference in scoring students' abilities on the material learned (Riana T Mangesa and Dyah D. Andayani, 2015). Through this competency-based learning, it is expected that the quality of graduates is more meaningful and has certain 
competencies according to environmental needs. In addition to the demands of basic skills and skills in the occupied field, the world of work requires employability skills of prospective workers. Employability skills are the ability to manage work attitude and behavior skills as expected by the industry / work world (Leish, 2002).

\section{Methods}

This study uses research and development methods by adopting the Borg and Gall (2005) model. The research subjects were undergraduate students in the Public Administration study program. Next the initial step of this research is a needs analysis starting with competency analysis based on the Indonesian National Qualification Framework (KKNI) curriculum, interviews with S1 Public Administration Study Program students to obtain competency information needed, problems related to competencies, as well as needs and prospects career in the future. In addition, a survey on the Public Management S1 study program was previously conducted to obtain data on the current Public Administration S1 curriculum as material and preliminary data for developing learning concepts in curriculum development. The conceptual model that has been designed is then presented and discussed in a Focus Group Discussion (FGD) involving practitioners (4 people), professional associations ( 1 person), and academics ( 3 people). The purpose of the FGD is to get agreement on the proposed model. The results of the FGD were validated using the Delphi technique which involved four curriculum experts with the aim of obtaining input related to the hypothetical model that had been formulated. Validation with the Delphi technique has the aim to get comments and ratings about the product to be tested with 4 criteria: (1) can be applied; (2) can be applied with minor revisions; (3) can be applied with major revisions; and (4) not yet implemented (Skulmoski, 2007). In addition to validating this hypothetical model, these experts were given five types of instruments, namely: (1) development guide assessment sheet, (2) model guide validation sheet, (3) competency achievement rubric sheet, (4) model feasibility assessment sheet, (5) ) and learning model effectiveness assessment sheets. 


\section{Results and Discussion}

Initial Product Design Development At this stage the instrument was validated through expert judgment. Instrument validation has the objective to find out whether the instruments developed in this study are suitable for use. In instrument validation, the validator provides an assessment and evaluates and provides suggestions for improving the instrument. The following is a summary of the results of the validator's assessment of the instrument in Table 4.1.

Table 4.1

Competencies of the World of Work Needs

\begin{tabular}{lll}
\hline \multicolumn{1}{c}{ Profesi } & \multicolumn{1}{c}{ Kompetensi } & \multicolumn{1}{c}{ Technical skills } \\
\hline Teknisi BogaProfesional & Mengetahui bidang perkerjaan & Employability Skill \\
(Cook, Captain waiter, Captain & Merencanakan variasi menu & Kerja tim \\
F\&B. Captain/Chief Baker. & Menghitung kebutuhan bahan makanan \& & Pemecahan masalah \\
Assistent Chief Steward, & minuman & \\
Assistant Chef De Partie, & Mengolah makanan dan minuman & Manajemen diri \\
Assisten Pastry Chef. & Menata dan menyajikan makanan \& minuman & Inisiatif \\
Bartender) & Memilih metode/alat pengolahan & Disiplin \\
& Melaksanakan Standar Operasional Prosedur & Jujur \\
& (SOP) & Bertanggungjawab \\
& Melaksanakan prinsip-prinsip manajeman & \\
& (POAC) & \\
& Mengawasi dan mengevaluasi pekerjaan & \\
& Merawat/maintenance alat pengolahan & \\
Supervisor di industry jasaboga & Menggunakan ICT dalam bidang kebogaan & \\
& Melaksanakan K3 (keamanan, keselamatan, dan & \\
& ketertiban) & \\
\hline
\end{tabular}

Table 4.2

Instrument Valuation Data by Valifdator

\begin{tabular}{|c|c|c|c|c|c|c|}
\hline \multirow{2}{*}{ Aspek yang Dinilai } & \multicolumn{6}{|c|}{ Rata-Rata Penilaian oleh Validator } \\
\hline & Inst. A & Inst. B & Inst. C & Inst. D & Inst. E & Inst. F \\
\hline $\begin{array}{l}\text { Petunjuk pengisian lembar validasi dinyatakan } \\
\text { dengan jelas }\end{array}$ & 1 & 1 & 0,75 & 1 & 1 & 0,75 \\
\hline Kriteria penilaian dinyatakan dengan jelas. & 0,75 & 1 & 0,75 & 0,75 & 0,75 & 1 \\
\hline $\begin{array}{l}\text { Tujuan penggunaan lembar validasi dirumuskan } \\
\text { dengan jelas dan terukur. }\end{array}$ & 1 & 0,75 & 1 & 1 & 1 & 1 \\
\hline $\begin{array}{l}\text { Aspek yang diukur dengan lembar validasi sudah } \\
\text { mencakup teori pendukung dan komponen- } \\
\text { komponen model. }\end{array}$ & 0,75 & 0,75 & 0,75 & 1 & 0,75 & 1 \\
\hline $\begin{array}{l}\text { Butir-butir yang dinyatakan untuk setiap aspek } \\
\text { penilaian pada lembar validasi sesuai dengan } \\
\text { tujuan pengukuran. }\end{array}$ & 1 & 1 & 0,75 & 1 & 1 & 0,75 \\
\hline $\begin{array}{l}\text { Rumusan butir-butir aspek penilaian pada lembar } \\
\text { validasi menggunakan kata pernyataan/perintah } \\
\text { yang menuntut pemberian nilai. }\end{array}$ & 1 & 0,75 & 0,75 & 1 & 0,75 & 1 \\
\hline $\begin{array}{l}\text { Rumusan aspek dan butir-butir aspek penilaian } \\
\text { pada lembar validasi menggunakan bahasa } \\
\text { Indonesia yang benar, sederhana, komunikatif, } \\
\text { dan mudah dipahami. }\end{array}$ & 1 & 0,75 & 0,75 & 0,75 & 1 & 0,75 \\
\hline $\begin{array}{l}\text { Rumusan aspek dan butir-butir aspek penilaian } \\
\text { pada lembar validasi tidak menggunakan kata-kata } \\
\text { atau kalimat yang menimbulkan penafsiran ganda. }\end{array}$ & 1 & 0,75 & 0,50 & 1 & 0,75 & 0,75 \\
\hline
\end{tabular}


Figure 4.1

Hypothetic Model

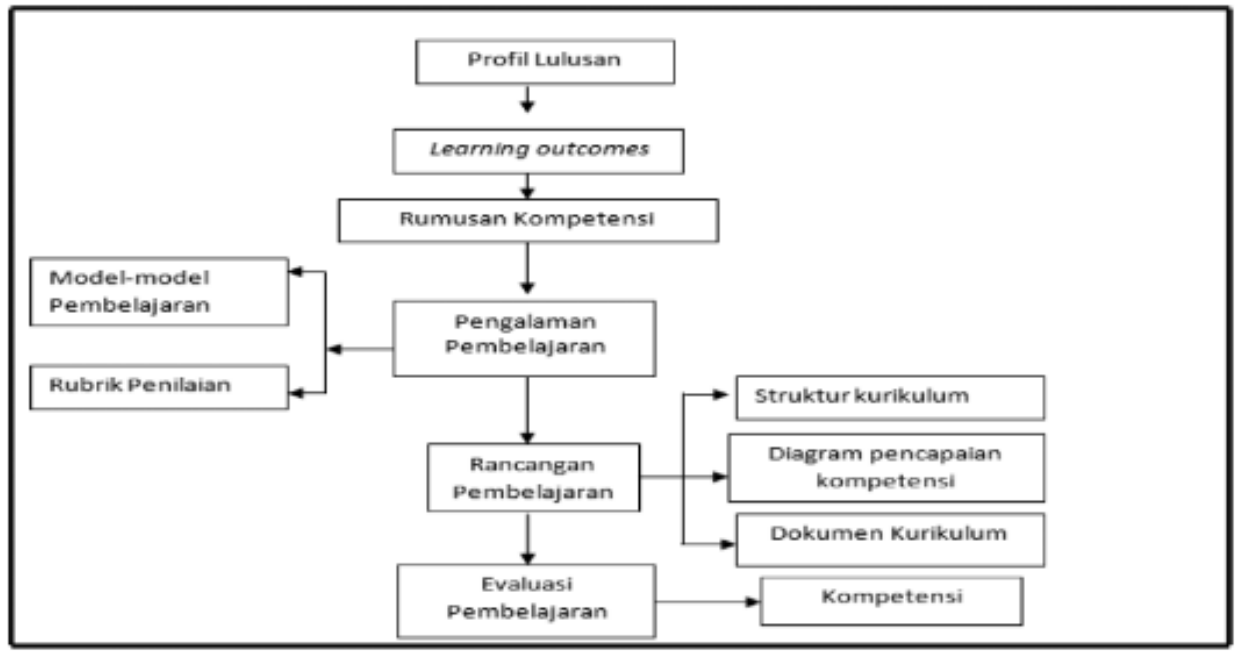

Based on Table 4 above, in general it can be seen that the results of the assessment by the validator are in good criteria. The assessment sheet criteria are said to be reliable if their reliability value $(\mathrm{R}) \geq 0.60$ (Sugiyono: 2017 ).

\section{Model Evaluation and Validation in FGD}

Conceptual models that have been validated through FGD activities produce hypothetical models. Figure 4.1 is a hypothetical model resulting from FGD validation. The Hypothetical Model developed in this study has previously been consulted and discussed with several experts representing the field of curriculum and learning in the field of Public Administration. Evaluation of this model has the aim to provide improvements to the stages of learning in the model developed so that the development goals of this model are achieved and can run effectively.

Figure 4. PKBK Empirical Model

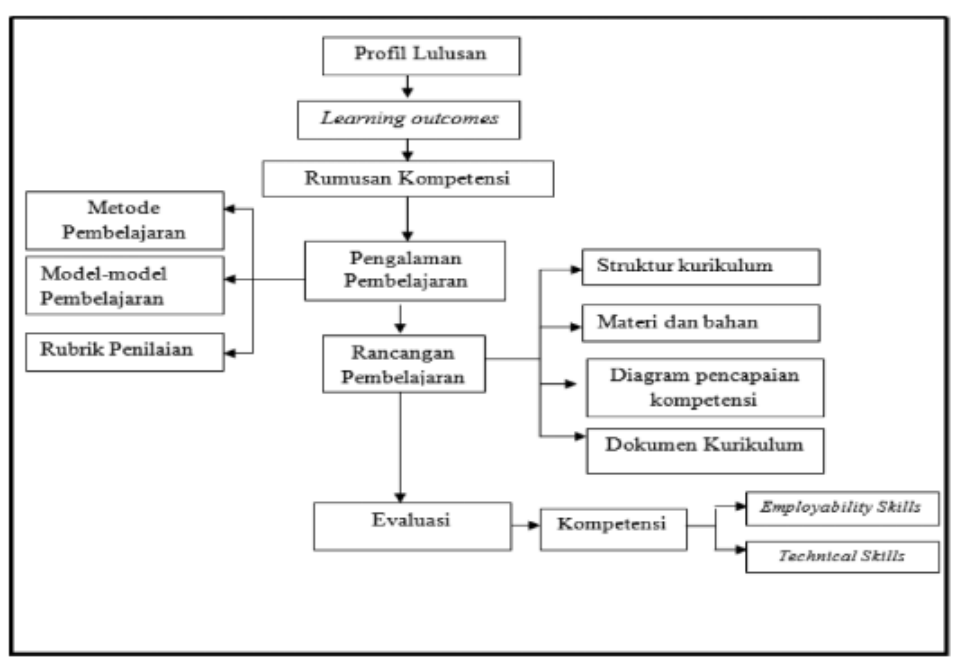


Based on the data described above, the results of the FGD and evaluation by experts obtained the PKBK empirical model with some important notes of the evaluation results are: (1) the need for a curriculum grouping in the curriculum structure; (2) managing competency achievement (learning outcomes) at each semester level; (3) lists various approaches, strategies and also learning models that are suitable for PKBK; (4) in the framework of the evaluation process it is necessary to describe what competency components will be evaluated. The PKBK empirical model shown in Figure 4.1 was proposed by Herminanto (2011) that learning must be presented in a contextual and authentic way, the content of learning must be designed to be relevant to student characteristics, the use of media and learning resources must be relevant to the development of the times needed so that student participation in learning is maximized .

\section{Conclusion}

Based on the results of research and development carried out, it can be concluded that the competency-based learning model with the work world approach (PKBK) produced has a graduate profile component, learning outcomes,formulation competency, learning experience, learning design, and competency evaluation. Second, the formulation of competencies for graduates of Public Administration S1 students based on industry needs is divided into 2 groups, namely technical skills and employability skills. Next learning design on the PKBK model consists of: curriculum structure, learning materials and materials, competency achievement diagrams and curriculum documents. Furthermore, the assessment rubric on the PKBK model contains an assessment of the employability skills and technical skills competencies.

\section{References}

Baharuddin. 2017.Model Pembelajaran Berbasis Kompetensi Bidang Pemanfaatan Tenaga Listrik di Sekolah. Jurnal Pendidikan Teknologi dan Kejuruan: Vol. 19 No. 1 April 2017. Hal: 53-61. 
Borg, W R \& Gall, M D. (2005). Educational research: an introduction, Fourth Edition. New York: Longman. Inc.

Febriana, Rina (2017) The Effectiveness Of A Competency-Based Learning Model Using World Of Work Approach At D3 Food And Nutrition Programme. Jurnal Cakrawala Pendidikan Vol 36. DOI - 10.21831/cp.v36i1.8891.

Herminanto Sofyan. 2011. Optimalisasi Pembe lajaran Berbasis Kompetensi Pada Pendidikan Kejuruan. Jurnal Pendidikan Vokasi Vol. 1, No. 1, hlm.113-131.

Kane, M. (1990). The Secretary's Commision on Achieving Necessary Skills (SCANS): Identifying and Describing The Skills Required by Work. Washington, D.C.: Pelavin Associates, Inc.

Leish Mc, A. (2002). Employability Skills for Australian Small and Medium Sized Enterprises: Report of the interviews and focus groups with small and medium enterprises. Department of Education, Science and Training.

Masitoh, Dewi L, Alinawati M, Permasih.(2009) Studi Implementasi Kurikulum Berbasis Kecakapan Hidup (Life Skills) Pada Jenjang Sekolah Dasar. Jurnal Penelitian Vol.10 No.2 Oktober 2009. Hal: 1-18

Munthe, B. (2009). Desain Pembelajaran. Yogyakarta : Pustaka Insan Madani.

Pardjono dan Windiyati Hestina, (2012). Implementasi Pembelajaran Berbasis Kompetensi Di SMK, Cakrawala Pendidikan, Juni 2012, Th. XXXI, No. 2.

Riana T. Mangesa dan Dyah D. Andayani. (2015). Pengembangan Model Pembelajaran Berbasis Kompetensi Bidang Kelistrikan di Sekolah Menengah Kejuruan. Cakrawala Pendidikan, Oktober 2015, Th. XXXIV, No. 3. Hal: 401-411

Schunk, D.H. (2008). Learning Theories: An Educational Perspective (5 ${ }^{\text {the }}$ ). Boston: Pearson Education.

Skulmoski, G.J, Hartman F.T, Krahn J. (2007). “The Delphi method for graduate research". Journal of Information Technology Education. 6, 1-21

Sugiyono. (2017). Metode Penelitian Kuantitatif, Kualitatif, dan R\&D. Bandung: Alfabeta Sunardi, M. Ihwanudin, Fitrianto Ferry Dwi. (2015). Pembelajaran Kolaboratif Berbasis Proyek: Inovasi Untuk Meningkatkan Kesesuaian Kompetensi Produktif Di SMK Dengan Kebutuhan Dunia Kerja. Seminar Nasional Teknologi Pendidikan UM, 2015. Hal. 140-153. 
Suherman, Amay. (2012). Pengembangan Desain Pembelajaran Berbasis Kompetensi Dalam Mempersiapkan Guru SMK RSBI Guna Memenuhi Tuntutan Standar Proses. Posiding Seminar Internasional, ISSN 1907-2066 Peran LPTK Dalam Pengembangan Pendidikan Vokasi di Indonesia. Hal 149-160.

Suparman, M.A. (2001) Desain Pembelajaran, Jakarta: Dirjen Dikti.

Suryadi D \& Yusa A. A.( 2009). Model Pembelajaran Berbasis Produksi Dengan Pendekatan Asesmen Portofolio Pada Perkuliahan Praktik Kerja Bangunan. Jurnal Penelitian Vol. 9 No. 1 April 2009. Hal: 1-15

Torres A. Scheopner, Brett J, Cox J., (2015). Competency-Based Learning: Definitions, Policies, and Implementation. Waltham. Education Development Center, Inc.

Widiyanto. (2011). “Peranan Kompetensi Pekerja Terhadap Kebutuhan Industri Untuk Meningkatkan Daya Saing Perusahaan. Jurnal Pendidikan terakreditasi". Eksplanasi, Vol.6 No.1, Maret 2011, hlm.94-108. 